\title{
lodide Retention by Modified Kaolinite in the Context of Safe Disposal of High Level Nuclear Waste
}

\author{
S. Sivachidambaram ${ }^{1}$ and Sudhakar M. Rao ${ }^{2}$
}

\begin{abstract}
Bentonite clay is identified as potential buffer in deep geological repositories (DGR) that store high level radioactive wastes (HLW) as the expansive clay satisfies the expected mechanical and physicochemical functions of the buffer material. In the deep geological disposal of HLW, iodine-129 is one of the significant nuclides, attributable to its long half-life (half life $=1.7 \times 10^{7}$ years). However, the negative charge on the basal surface of bentonite particles precludes retention of iodide anions. To render the bentonite effective in retaining hazardous iodide species in DGR, improvement of the anion retention capacity of bentonite becomes imperative. The iodide retention capacity of bentonite is improved by admixing 10 and 20\% Ag-kaolinite (Ag-K) with bentonite (B) on a dry mass basis. The present study produced Ag-kaolinite by heating silver nitrate-kaolinite mixes at $400^{\circ} \mathrm{C}$. Marginal release of iodide retained by Ag-kaolinite occurred under extreme acidic $(\mathrm{pH}=2.5)$ and alkaline $(\mathrm{pH}=12.5)$ conditions. The swell pressure and iodide retention results of the $\mathrm{B}-\mathrm{Ag}-\mathrm{K}$ specimens bring out that mixing Ag-K with bentonite does not chemically modify the expansive clay; the mixing is physical in nature and Ag-K presence only contributes to iodide retention of the admixture. DOI: 10.1061/(ASCE)HZ.2153-5515.0000121. (C) 2012 American Society of Civil Engineers.
\end{abstract}

CE Database subject headings: Bentonite; Radioactive wastes; Waste management.

Author keywords: Bentonite; Iodide; Radionuclides; Repository; Retention.

\section{Introduction}

In the deep geological disposal of radionuclides, iodine-129 is one of the significant nuclides, attributable to its long half-life (half life $=1.7 \times 10^{7}$ years) and tendency to easily migrate out of the geological repository into the biosphere caused by its high solubility and poor sorption onto most geologic media (Sazarashi et al. 1994; Balsley et al. 1998). Therefore, studies have focused on developing methods for immobilization of iodide ions with a view to apply these results toward iodide retardation in the geological repository environment. Balsley et al. (1998) examined the iodide sorption capacity of copper sulfides, imogolite-rich soils, hydrotalcites, copper-oxides, lignite coal, and calcium monosulfate aluminate toward iodide ions and observed that the iodide ions have preference to specific minerals depending on the solution $\mathrm{pH}$. Sazarashi et al. (1994) observed that iodide ions are not appreciably adsorbed on minerals, such as allophane, attapulgite, and montmorillonite. Toyohara et al. (2000) examined the iodide sorption capacity of mixed alumina cement-calcium compounds. Their experimental results suggested that iodide sorption by calcium aluminate occurs by replacement of hydroxyl ions by iodide ions. Balsley et al. (1998) also noted that specific cement phase-calcium monosulfate aluminate hydrate possess a high sorption capacity for iodide ions.

\footnotetext{
${ }^{1}$ Research Student Centre for Sustainable Technologies, Indian Institute of Science, Bangalore 560012, India. E-mail: sivani@astra.iisc.ernet.in

${ }^{2}$ Professor, Dept. of Civil Engineering and Chairman, Centre for Sustainable Technologies, Indian Institute of Science, Bangalore 560012, India (corresponding author).E-mail: msrao@civil.iisc.ernet.in

Note. This manuscript was submitted on October 15, 2010; approved on June 29, 2011; published online on July 1, 2011. Discussion period open until December 1, 2012; separate discussions must be submitted for individual papers. This paper is part of the Journal of Hazardous, Toxic, and Radioactive Waste, Vol. 16, No. 3, July 1, 2012. (CASCE, ISSN 21535493/2012/3-192-200/\$25.00.
}

The canisters containing the HLW on placement in DGR need protection against tectonic activities and chemical attack by dissolved elements and from microbes (Pusch 2008). Densely compacted bentonite is identified suitable for this purpose because of its large swell potential, low permeability, sufficient bearing capacity, and high cation adsorption capacity (Pusch 2008). By virtue of negatively charged basal surface, bentonite clay has negligible affinity for retention of anions (van Olphen 1963). Attempts have been made to improve the iodide retention capacity of bentonite by treating the clay with cationic polymers (Dultz and Bors 2000; Riebe et al. 2005; Kaufhold et al. 2007). In a recent study, Inyang et al. (2007) examined the effect of aqueous polymers on the swelling of sodium montmorillonite. Their results illustrated that the cationic polymer polyacylamide reduces the volumetric swelling ratio of sodium montmorillonite by $40 \%$ relative to distilled water. Polycations are almost irreversibly adsorbed by Coulombic interaction on the clay surface (Breen 1999), which is apparently responsible for the reduction in swell potential of sodium montmorillonite clays on treatment with cationic polymers. To circumvent this problem, Kaufhold et al. (2007) resorted to adding $5 \%$ of hexadecylpyridinium treated bentonite to $95 \% \mathrm{MX}-80$ bentonite; this small addition was observed not to affect the swelling pressure of compacted MX-80 clay. As large swell potential is a key property of bentonite buffer to maintain tight contact between the canisters and the surrounding rock and treatment with polycations may possibly reduce the swelling capacity, an alternate method for improving the iodide sorption capacity of bentonite is examined.

\section{Scope of the Study}

Sazarashi et al. (1994) observed that minerals, such as mercury sulfide (HgS, Cinnabar) containing metal ions capable of forming insoluble iodides (mercury iodide) have higher adsorption capacities for iodide ions than minerals that retain anion 
through ion-exchange reactions. In addition to mercury, silver compounds such as silver oxide form insoluble halides through reactions of the type (Cotton et al. 1995)

$$
\begin{gathered}
\mathrm{AgO}+\mathrm{H}_{2} \mathrm{O} \longrightarrow \mathrm{AgOH}+\mathrm{OH}^{-} \\
\mathrm{AgOH}+\mathrm{I}^{-} \longrightarrow \mathrm{AgI}+\mathrm{OH}^{-}
\end{gathered}
$$

Daniels and Rao (1983) examined the sorption of silver ions by kaolinite at room temperature $\left(25^{\circ} \mathrm{C}\right)$ and elevated temperatures $\left(255-290^{\circ} \mathrm{C}\right)$. The workers noted that $35 \mathrm{meq} / 100 \mathrm{~g}$, $63 \mathrm{meq} / 100 \mathrm{~g}, 83 \mathrm{meq} / 100 \mathrm{~g}$, and $106 \mathrm{meq} / 100 \mathrm{~g}$, of silver ions are sorbed by kaolinite at temperatures of $25^{\circ} \mathrm{C}, 255^{\circ} \mathrm{C}, 275^{\circ} \mathrm{C}$, and $290^{\circ} \mathrm{C}$, respectively. Guided by the increased amounts of silver retention at elevated temperatures, the present study produced Ag-kaolinite by heating silver nitrate-kaolinite mixes at $400^{\circ} \mathrm{C}$. Bentonite-Ag-kaolinite mixes containing 0, 10\%, and $20 \%$ Ag-kaolinite on a dry weight basis are prepared and examined for iodide sorption from aqueous sodium iodide solutions. Iodide measurements were performed using ion chromatograph method. This study presumes that the results obtained for nonradioactive iodide-127 species employed would be applicable to the radioactive iodide-129 species encountered in deep geological repositories for HLW. The Ag- kaolinite content in the bentonite mix is restricted on the basis of the I-127 concentrations encountered under field conditions and the effect of Ag-kaolinite dilution on the swell pressure of the compacted mixes.

\section{Materials and Methods}

Commercially obtained kaolinite (Alminrock and Chemicals, Bangalore, India), natural bentonite from Rajasthan, India, analytical reagent grade silver nitrate $\left(\mathrm{AgNO}_{3}\right)$, and sodium iodide $(\mathrm{NaI})$ salts were used in the laboratory experiments. The physical and chemical properties of kaolinite and bentonite specimens are provided in Table 1. The specific gravity of kaolinite and bentonite were determined as per Bureau of Indian Standards (BIS) (1980a) and corresponds to 2.64 and 2.69, respectively. The grain size distributions of the clay specimens were determined as per BIS (1985a). Kaolinite is mostly a silty material (silt fraction $=87 \%$, size range 75 to $2 \mu$ ) with $12 \%$ clay-sized fraction $(<2 \mu)$, whereas the bentonite predominates in clay-sized fraction $(86 \%)$. The Atterberg limits of kaolinite and bentonite were determined as per BIS (1985b). Kaolinite has liquid limit of $31 \%$ and plasticity index of $3 \%$, and classifies as ML as per Unified Soil Classification System (USCS). Despite its silty nature, the mineral is essentially composed of kaolinite as revealed by the XRD pattern in Fig. 1 that shows prominent peaks at $0.714,0.314$, and $0.234 \mathrm{~nm}$ characteristic of this 1:1 nonexpanding mineral. Comparatively, bentonite has a liquid limit of $314 \%$ and plasticity index of $279 \%$, and classifies as $\mathrm{CH}$ as per USCS classification for inorganic clays of high plasticity. The compaction characteristics of the clay minerals were determined as per BIS (1980b). The standard Proctor maximum dry density (MDD) and optimum moisture content (OMC) values of bentonite, correspond to $1.37 \mathrm{Mg} / \mathrm{m}^{3}$ and $29 \%$; the corresponding values for kaolinite and $\mathrm{Ag}$-kaolinite were $1.40 \mathrm{Mg} / \mathrm{m}^{3}$ and $31 \%$ and $1.39 \mathrm{Mg} / \mathrm{m}^{3}$ and $30 \%$, respectively.

The external surface of kaolinite was determined by the BET $N_{2}$ adsorption method and corresponds to $8 \mathrm{~m}^{2} / \mathrm{g}$. The total surface area of bentonite was determined by the ethylene glycol adsorption method (Pennell 2002) and corresponds to $551 \mathrm{~m}^{2} / \mathrm{g}$. The exchangeable calcium, magnesium, sodium, and potassium ion contents of kaolinite and bentonite specimens were determined

\begin{tabular}{|c|c|c|}
\hline Property & Kaolinite & Bentonite \\
\hline Specific gravity & 2.64 & 2.69 \\
\hline \multicolumn{3}{|c|}{ Particle size distribution (\%) } \\
\hline Sand & 1 & 2 \\
\hline Silt & 87 & 12 \\
\hline Clay & 12 & 86 \\
\hline Liquid limit (\%) & 31 & 314 \\
\hline Plasticity index (\%) & 3 & 279 \\
\hline USCS classification & ML & $\mathrm{CH}$ \\
\hline $\operatorname{MDD}\left(\mathrm{Mg} / \mathrm{m}^{3}\right)$ & 1.40 & 1.37 \\
\hline $\mathrm{OMC}(\%)$ & 31 & 29 \\
\hline Surface area $\left(\mathrm{m}^{2} / \mathrm{g}\right)$ & 8 & 551 \\
\hline CEC (meq/100 g) & 2.1 & 81 \\
\hline $\mathrm{Ca}$ & 0.6 & 18 \\
\hline $\mathrm{Mg}$ & 0.6 & 15 \\
\hline $\mathrm{Na}$ & 0.8 & 47 \\
\hline K & 0.1 & 1 \\
\hline \multicolumn{3}{|c|}{ Chemical composition (\%) } \\
\hline $\mathrm{SiO}_{2}$ & 51 & 60 \\
\hline $\mathrm{Al}_{2} \mathrm{O}_{3}$ & 33 & 18 \\
\hline $\mathrm{Fe}_{2} \mathrm{O}_{3}$ & 1 & 10 \\
\hline $\mathrm{CaO}$ & 0.15 & 2 \\
\hline $\mathrm{MgO}$ & 0.13 & 2 \\
\hline $\mathrm{Na}_{2} \mathrm{O}$ & 0.22 & 2 \\
\hline $\mathrm{K}_{2} \mathrm{O}$ & 0.2 & 2 \\
\hline Loss on ignition (\%) & 13.5 & 4 \\
\hline
\end{tabular}

Table 1. Physical and Chemical Properties of Kaolinite and Bentonite

by equilibrating the specimens with neutral $1 \mathrm{M}$ ammonium acetate solution to displace the exchangeable calcium, magnesium, sodium, and potassium ions by ammonium ions (Hesse 1971). The cation exchange capacity (CEC) of the clay specimens were determined by summing the concentrations of the displaced calcium, magnesium, sodium, and potassium ion contents. The concentrations of the displaced calcium, sodium, and potassium and magnesium ions were determined using an inductively coupled plasma-optical emission spectrometer (ICP-OES). Kaolinite has a CEC of $2.1 \mathrm{meq} / 100 \mathrm{~g}$ and bentonite has a CEC of

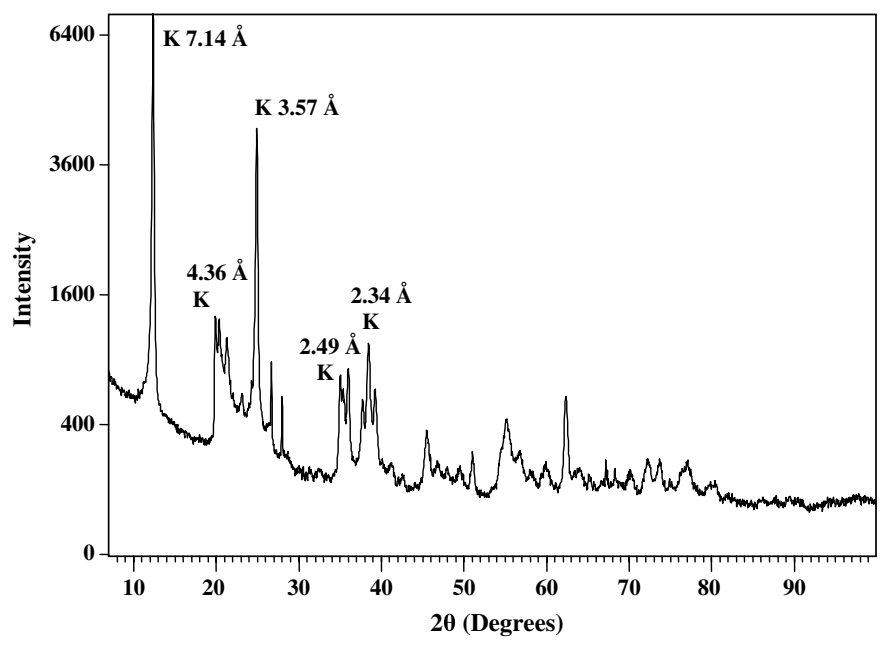

Fig. 1. XRD pattern of kaolinite 
$81 \mathrm{meq} / 100 \mathrm{~g}$. The chemical composition of kaolinite and bentonite were determined by digesting the clays using microwave digestor and determining the inorganic constituents in the acid extract by ICP-OES (Hossner 2002).

\section{Silver Sorption and Kinetics Experiments}

Silver nitrate melts at $212^{\circ} \mathrm{C}$ and decomposes on heating at temperature of $440^{\circ} \mathrm{C}$ (Perry et al. 1999) according to the reaction

$$
\mathrm{AgNO}_{3}===\text { heat }===\mathrm{AgO}+\mathrm{NO}_{2}
$$

The thermogram in Fig. 2 illustrates that silver nitrate decomposition commences around $400^{\circ} \mathrm{C}$. Decomposition of $\mathrm{AgNO}_{3}$ to $\mathrm{AgO}$ should yield $27 \%$ weight loss through the reaction (3). The thermogram in Fig. 2 illustrates that $\mathrm{AgNO}_{3}$ experiences approximately $45 \%$ weight loss on heating at $400^{\circ} \mathrm{C}$. The additional weight loss is attributed to loss of adsorbed water molecules from the silver nitrate crystals. Because thermal decomposition of silver nitrate to $\mathrm{AgO}$ is a prerequisite for iodide retention (reactions 1 and 2), the silver nitrate-kaolinite mixtures were heated at $400^{\circ} \mathrm{C}$. A $20 \%$ silver nitrate- $80 \%$ kaolinite mixture (on dry mass basis) was selected as preparation for the silver-kaolinite phase, as sorption experiments with $1 \%, 5 \%, 10 \%, 20 \%, 25 \%$, and $30 \%$ silver nitrate-kaolinite mixes revealed that silver retention by kaolinite reaches near equilibrium at this silver nitrate concentration (Fig. 3). Further, the heating duration was restricted to $30 \mathrm{~min}$ as kinetic experiments conducted with $20 \%$ silver nitrate- $80 \%$ kaolinite mixes illustrated the amount of silver retained by kaolinite attained equilibrium for this heating period (Fig. 4). In the sorption and kinetics experiments, the heated silver nitrate-kaolinite mixtures were washed with distilled water until the washings were free of unreacted silver ions; the washed samples were oven-dried at $105^{\circ} \mathrm{C}$ and stored in amber bottles until use. The total amounts of silver retained by kaolinite in the sorption and kinetics experiments were estimated by dissolution of the washed silver-kaolinite samples in a microwave digestor and determination of the dissolved silver in the digestor extract using an inductively coupled plasmaoptical emission (ICP-OES) spectrometer. The washed and ovendried specimens obtained by heating the $20 \%$ silver nitrate- $80 \%$ kaolinite mixture at $400^{\circ} \mathrm{C}$ for $30 \mathrm{~min}$ are referred as Ag-kaolinite specimens. The Ag-kaolinite will be designated as Ag-K in further discussions, whereas bentonite is designated as B.

\section{Characterization of Ag-Kaolinite}

To estimate the amount of exchangeable silver, the Ag-K specimen was extracted with neutral ammonium acetate solution and the amount of silver in the ammonium extract was determined using the ICP-OES method. The difference between the total silver and exchangeable silver estimated the amount of nonexchangeable

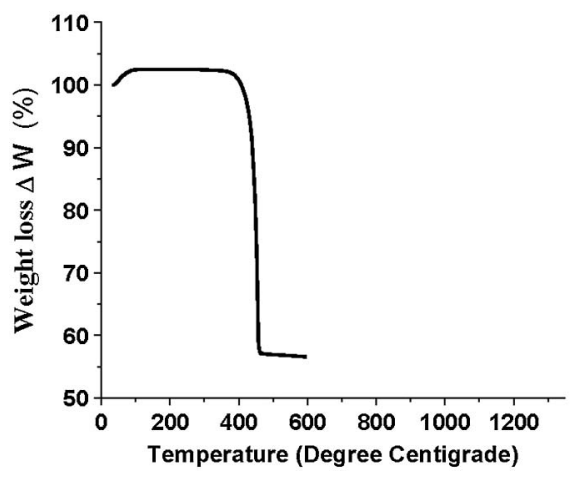

Fig. 2. Thermogram of silver nitrate

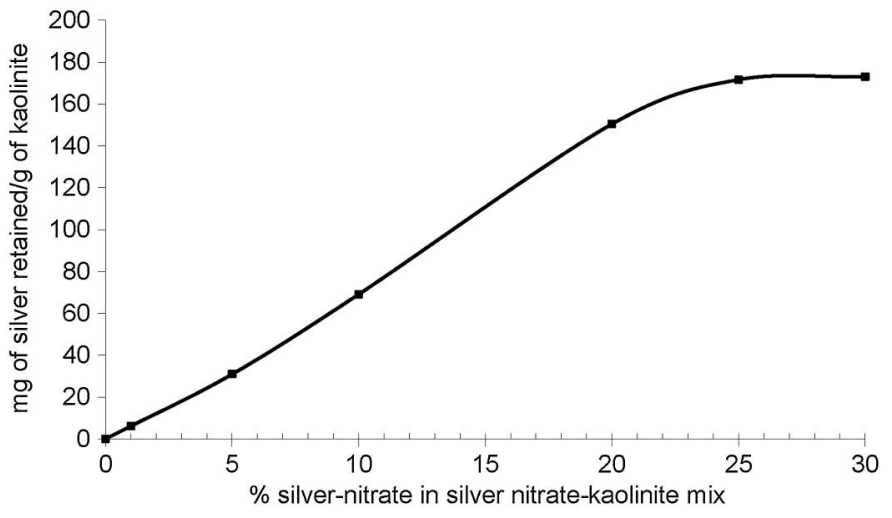

Fig. 3. Influence of initial silver nitrate concentration on silver retention by kaolinite

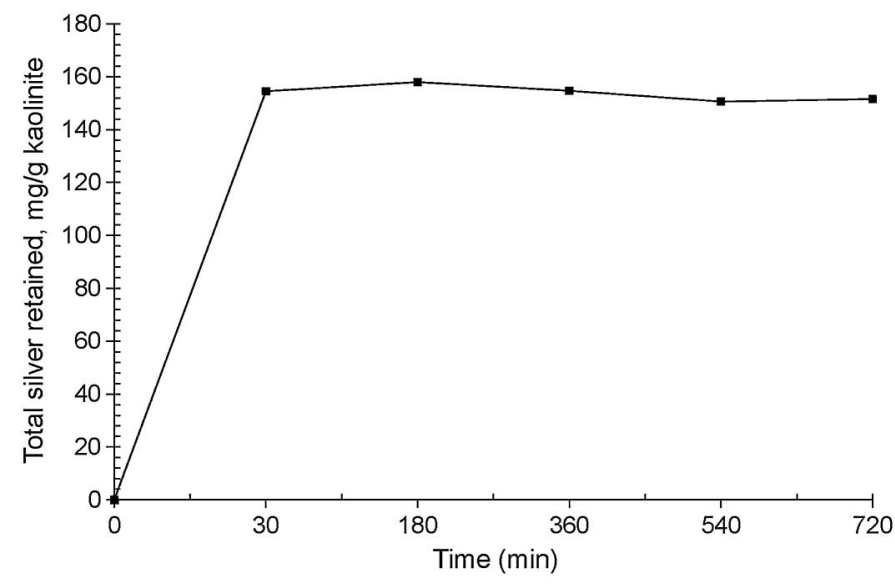

Fig. 4. Time-rate of silver retention by kaolinite

silver available in the Ag-K specimen. X-ray diffraction (XRD) analysis ( $2 \theta$ range, $5-15^{\circ}$, scan rate $1^{\circ} / \mathrm{min}$ ) were performed with kaolinite and $\mathrm{Ag}-\mathrm{K}$ specimens. Differential scanning calorimetry (DSC) analyses were performed with silver nitrate salt from ambient $\left(25^{\circ} \mathrm{C}\right)$ to $1,500^{\circ} \mathrm{C}$ at a heating rate of $10^{\circ} \mathrm{C} / \mathrm{min}$.

The external surface area of Ag-K was determined by BET $\mathrm{N}_{2}$ adsorption method and corresponds to $7 \mathrm{~m}^{2} / \mathrm{g}$; its cation exchange capacity determined by ammonium acetate extraction corresponds to $1 \mathrm{meq} / 100 \mathrm{~g}$.

\section{lodide Sorption by Ag-Kaolinite and Ag-Kaolinite + Bentonite Specimens}

Iodide sorption by Ag-kaolinite (designated as Ag-K), $90 \%$ bentonite $+10 \%$ Ag-K specimen (designated as 90B-10AgK), and $80 \%$ bentonite $+20 \%$ Ag-K specimen (designated as $80 \mathrm{~B}-20 \mathrm{AgK}$ ) was determined as function of initial iodide concentration to estimate the iodide retention capacity of each mix. In these experiments, $0.5 \mathrm{~g}$ of the material was equilibrated with $50 \mathrm{ml}$ batches of $\mathrm{NaI}$ solutions (iodide concentration range, $90 \mathrm{mg} / \mathrm{L}$ to $1,000 \mathrm{mg} / \mathrm{L}$ ) for $30 \mathrm{~min}$ using a horizontal mechanical shaker. The 30 min duration was on the basis of the results of the separately conducted kinetics experiments whose results are not reported in the present study. At the end of the given equilibration period in the retention capacity experiments, the suspensions were filtered and the iodide concentrations in the filtrates were determined by ion chromatograph method. The difference between 
initial and final iodide concentration was used to calculate the amount of iodide retained by the $\mathrm{Ag}-\mathrm{K}$ and $\mathrm{B}-\mathrm{Ag}-\mathrm{K}$ specimens. $\mathrm{Ag}-\mathrm{K}$ specimen contacted with $1,000 \mathrm{mg} / \mathrm{L}$ iodide solution for 30 min was subjected to XRD analysis to detect any AgI (silver iodide) phase formation. To examine the influence of longer contact period on iodide sorption, $0.5 \mathrm{~g}$ of $\mathrm{Ag}-\mathrm{K}$ was also agitated with $50 \mathrm{ml}$ of $1,000 \mathrm{mg} / \mathrm{L}$ iodide solution for $24 \mathrm{~h}$; following agitation, the amount of iodide retained by $\mathrm{Ag}-\mathrm{K}$ was calculated as described previously. The amount sorbed after $24 \mathrm{~h}$ of equilibration (59 meq/100 g) was near identical to that sorbed after $30 \mathrm{~min}$ of equilibration (58 meq/100 g).

All other factors being similar, the capacity of $\mathrm{Ag}-\mathrm{K}$ to retain iodide ions would depend on the purity of the kaolinite mineral and the fines content (silt + clayfractions). As previously noted, the XRD pattern of kaolinite (Fig. 1) shows reflections pertaining to kaolinite alone. Presence of other clay minerals,for example illite/montmorillonite, would tend to reduce the silver sorption and, in turn, the iodide sorption values. Similarly, the kaolinite used in the study is characterized by $99 \%$ fines content (Table 1, silt $=87 \%$ and clay $=12 \%$ ). Reduction in fines content would reduce the sorption sites for silver uptake and, in turn, the iodide sorption.

Leaching tests were performed with iodide sorbed Ag-K specimens at $\mathrm{pH}$ ranging from 2.5 to 12.5. Iodide sorbed $\mathrm{Ag}-\mathrm{K}$ specimens were produced by agitating $\mathrm{Ag}-\mathrm{K}$ with $500 \mathrm{mg} / \mathrm{L}$ iodide solution for $30 \mathrm{~min}$. After agitation, the clay material was filtered and repeatedly washed with distilled water to remove free iodide. The washed specimens were agitated (using mechanical shaker) with strongly acidic $(\mathrm{pH}=2.5)$ to strongly alkaline $(\mathrm{pH}=12.5)$ aqueous solutions for $1 \mathrm{~h}$; the suspensions were filtered and iodide concentrations in the filtrates were measured using ion chromatograph. The $\mathrm{pH}$ of the aqueous solutions was adjusted using $0.001 \mathrm{MHN} \mathrm{O}_{3}$ and $0.001 \mathrm{M} \mathrm{NaOH}$ solutions.

\section{Zeta Potential Measurements}

Zeta potential measurements were performed on kaolinite and $\mathrm{Ag}-\mathrm{K}$ specimens to investigate the changes in surface charge characteristics of kaolinite on silver sorption and of Ag-K specimen on iodide sorption at range of $\mathrm{pH}$ values (3-11). The zeta potential measurements were performed using electroacoustic method that automatically measured the zeta potential of the clay suspensions (2\% suspension on weight basis) as a function of $\mathrm{pH}$ at $25^{\circ} \mathrm{C}$. Potassium nitrate $(0.001 \mathrm{M})$ was employed as the electrolyte in the zeta potential measurements on kaolinite and Ag-K suspensions. To examine the influence of iodide sorption on the surface charge characteristics of Ag-K specimen, zeta potential measurements were performed on Ag-K suspension (1.9\%) using $0.01 \mathrm{M}$ sodium iodide solution as the electrolyte solution at range (3-11) of $\mathrm{pH}$ values. The $1.9 \% \mathrm{Ag}-\mathrm{K}$ suspension refers to $1.9 \mathrm{~g}$ of mineral suspended in $100 \mathrm{ml}$ of $0.01 \mathrm{M}$ sodium iodide solution.

\section{Swell Potential and Swell Pressure Measurements}

Oedometer swell potential tests were performed using compacted bentonite and 80B-20AgK specimens. The bentonite and 80B-20AgK specimens were remolded with a known volume of distilled water to yield specimens characterized by $25 \%$ moisture content (corresponding to standard Proctor optimum moisture content of the $80 \mathrm{~B}-20 \mathrm{AgK}$ specimen); the moist specimens were statically compacted in $76-\mathrm{mm}$ diameter oedometer rings (specimen thickness $=8 \mathrm{~mm}$ ) to dry density of $1.5 \mathrm{Mg} / \mathrm{m}^{3}$ (corresponding to standard Proctor maximum dry density of 80B-20AgK). The standard Proctor MDD and OMC values of bentonite $\left(1.37 \mathrm{Mg} / \mathrm{m}^{3}\right.$ and $\left.29 \%\right)$ differ from those of the 80B-20AgK specimen $\left(1.5 \mathrm{Mg} / \mathrm{m}^{3}\right.$ and $\left.25 \%\right)$. However, bentonite was tested at the same dry density and water content as the $80 \mathrm{~B}-20 \mathrm{AgK}$ specimen as the swell percent and swell pressure are affected by the compaction characteristics of the clay (Rao 2006). The compacted clay specimens were inundated with distilled water at net vertical stress of $6.25 \mathrm{kPa}$ in separate oedometer assemblies. The swelling strains of the compacted specimens were monitored until they became nearly constant. Periods ranging from 20 to 22 days were needed for the swelling strains of the compacted specimens to become constant. The percent swell of the compacted specimens on inundation with distilled water at time interval $t$ was calculated as

$$
\% \text { swell }=\frac{\Delta H}{H_{i}} \times 100 \%
$$

In Eq. (4), $\Delta H$ represents the increase in height of the wetted specimen at time $t$ and $H_{i}$ represents the initial height of the compacted specimen.

Swell pressure measurements were performed with compacted (dry density $=1.50 \mathrm{Mg} / \mathrm{m}^{3}$ and moisture content $=25 \%$ ) bentonite, 90B-10AgK, 80B-20AgK, 70B-30AgK, and 50B-50AgK specimens using the constant volume method. The compacted specimens contained in conventional oedometer cells (diameter $=$ $60 \mathrm{~mm}$ ) were placed in a triaxial loading frame. On inundation with distilled water, the specimens were prevented from swelling by the reaction developed in the rigid loading frame. The swelling stresses developed in the specimen (as swelling strains are prevented) were measured using a load cell as a function of time. The swelling stress at equilibrium is defined as swell pressure. The swelling stress of $50 \mathrm{~B}-\mathrm{Ag}-\mathrm{K}$ specimen became nearly constant in approximately $15 \mathrm{~min}$, whereas the swelling stress of bentonite specimen needed $44 \mathrm{~h}$ to attain constant value.

\section{Results and Discussion}

\section{Mechanism of Silver Retention by Kaolinite}

Table 2 details the gravimetric weight loss measurements conducted on $1.25 \mathrm{~g}$ of $80 \mathrm{~B}-20 \mathrm{AgK}$ specimen (constituted by $1.0 \mathrm{~g}$ of kaolinite and $0.25 \mathrm{~g}$ of silver nitrate) on heating at $400^{\circ} \mathrm{C}$ for $30 \mathrm{~min}$. According to reaction 3, $0.25 \mathrm{~g}$ of silver nitrate salt should experience $0.07 \mathrm{~g}$ of weight loss on complete decomposition. The silver nitrate + kaolinite mix experiences weight loss of $0.12 \mathrm{~g}$ (Table 2) under the experimental heating conditions; the additional weight loss of $0.05 \mathrm{~g}$ experienced by the mix is explained from the results of Kallai (1978). On heating kaolinite-salt mixes at temperatures below $600^{\circ} \mathrm{C}$, the kaolinite mineral experiences saltcatalyzed dehydroxylation. The reaction commences with the dehydroxylation of kaolinite; the water liberated during dehydroxylation dissolves the salt particles that further catalyze the dehydroxylation reaction. In line with the observations of Kallai (1978), the additional weigh loss of $0.05 \mathrm{~g}$ on heating the silver nitrate-kaolinite mix is attributed to the salt-catalyzed dehydroxylation of kaolinite.

Table 2. Weight Loss on Heating Silver Nitrate-Kaolinite Mix

\begin{tabular}{lccc}
\hline Material & Initial mass $(\mathrm{g})$ & $\begin{array}{c}\text { Mass }(\mathrm{g}) \text { after } \\
\text { heating at } 400^{\circ} \mathrm{C}\end{array}$ & $\begin{array}{c}\text { Weight } \\
\text { loss }(\mathrm{g})\end{array}$ \\
\hline $20 \%$ silver nitrate + & $\begin{array}{c}1.25(0.25 \mathrm{~g} \\
\text { silvernitrate }+ \\
\text { kaolinite mix }\end{array}$ & 1.13 & 0.12 \\
& $1 \mathrm{~g}$ kaolinite $)$ & & \\
\hline
\end{tabular}


Table 3. Amount of Silver Retained by Kaolinite on Heating $20 \%$ Silver Nitrate-Kaolinite Mix

\begin{tabular}{lcc}
\hline $\begin{array}{l}\text { Total silver retained } \\
\text { by kaolinite }(\mathrm{mg} / \mathrm{g})\end{array}$ & $\begin{array}{c}\text { Nonexchangeable } \\
\text { silver }(\mathrm{mg} / \mathrm{g})\end{array}$ & $\begin{array}{r}\text { Exchangeable } \\
\text { silver }(\mathrm{mg} / \mathrm{g})\end{array}$ \\
\hline $150(139)$ & $135(125)$ & $15(14)$ \\
\hline
\end{tabular}

Note: Values in parentheses are in terms of meq/100 $\mathrm{g}$.

Reaction 3 predicts that decomposition of $0.25 \mathrm{~g}$ of silver nitrate in the $20 \%$ silver nitrate-kaolinite mix should yield $0.18 \mathrm{~g}$ of $\mathrm{AgO}$ (or $160 \mathrm{mg}$ of nonexchangeable silver) per $g$ of kaolinite. Table 3 provides the amount of silver retained by the kaolinite specimen on heating the $20 \%$ silver nitrate- $80 \%$ kaolinite mix at $400^{\circ} \mathrm{C}$ for $30 \mathrm{~min}$. Heating the mix caused $150 \mathrm{mg}$ of silver to be retained per $g$ of kaolinite; further, $15 \mathrm{mg}$ (of the $150 \mathrm{mg}$ of silver) occurred in the exchangeable form (on the basis of on ammonium acetate extraction results, Table 3). Comparing the nonexchangeable amounts of silver determined experimentally $(135 \mathrm{mg})$ and predicted from reaction $3(160 \mathrm{mg})$ indicates that nearly $85 \%$ of silver nitrate in the (20\% salt-clay) mix participates in the thermal decomposition reaction.

The size of an $\mathrm{AgO}$ molecule is $0.18 \mathrm{~nm}$. XRD patterns of kaolinite and $\mathrm{Ag}-\mathrm{K}$ specimens were obtained for the $2 \theta$ range of $5-15^{\circ}$ (Fig. 5). The XRD pattern of the Ag-K specimen shows 001 spacing at $0.716 \mathrm{~nm}$, whereas the corresponding spacing for kaolinite occurs at $0.714 \mathrm{~nm}$. The 001 spacing represents the distance between two unit layers of a clay mineral (van Olphen 1963). Intercalation of an $\mathrm{AgO}$ molecule between the unit layers of kaolinite ought to have increased its 001 spacing to $0.894 \mathrm{~nm}$ $(0.714 \mathrm{~nm}+0.18 \mathrm{~nm})$. Therefore, the similar 001 (c-axis) spacings of kaolinite and $\mathrm{Ag}-\mathrm{K}$ specimens imply that the $\mathrm{AgO}$ molecules are not intercalated in the interlayer space of kaolinite but are retained on the surface. Combining the results of mass balance calculations, amounts of silver retained by kaolinite, and XRD analysis, shows that on heating a $20 \%$ silver nitrate-kaolinite mix, $85 \%$ of silver nitrate contained in the mix participates in the thermal decomposition reaction with the reactions product being retained on the clay surface.

Fig. 6 plots the zeta potential of kaolinite and Ag-K specimens as a function of suspension $\mathrm{pH}$. Kaolinite is characterized by negative zeta potential of -4.5 to -9.9 millivolts over the $\mathrm{pH}$ range of 2.9 to 9.9 and, consequently, does not exhibit an isoelectric point (IEP). The $\mathrm{pH}$ of kaolinite suspensions were artificially varied between 2.9 and 9.9 by adding dilute nitric acid or sodium hydroxide
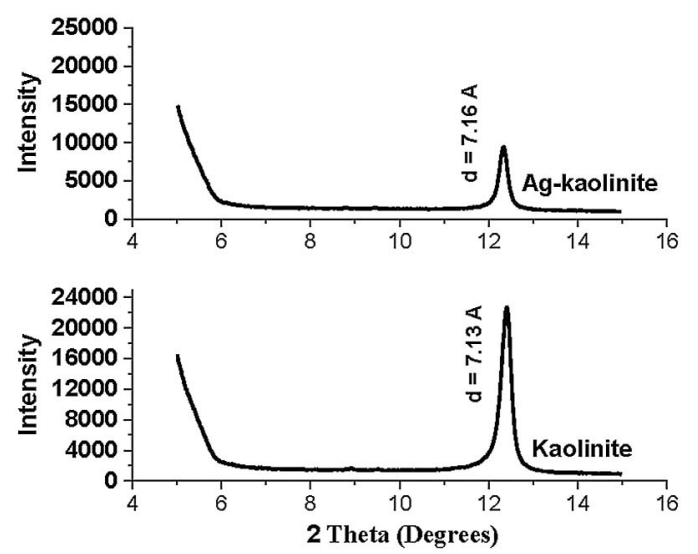

Fig. 5. XRD patterns of kaolinite and Ag-kaolinite for the $2 \theta$ range of $5-15^{\circ}$

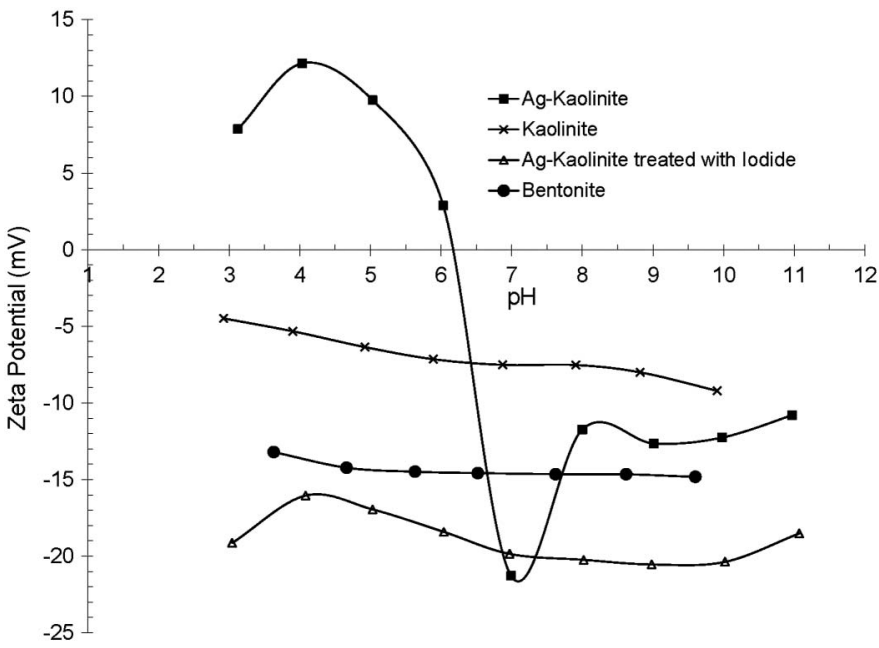

Fig. 6. Zeta potential measurements as function of $\mathrm{pH}$

solutions to examine the zeta potential of the clay over a wide range of $\mathrm{pH}$ values. Significant variations exist in the reported zeta potential of kaolinite specimens (Yukselen and Kaya 2003); in the alkaline $\mathrm{pH}$ range (10-11), the kaolinite suspensions exhibit zeta potential of -30 to -85 millivolts and, in the acid (2-3) $\mathrm{pH}$ range, -25 to $10 \mathrm{mV}$. In the present study, the kaolinite suspension exhibits a lower range of zeta potentials compared with values reported in the literature, indicating smaller diffuse ion layer formation (Yukselen and Kaya 2003). On silver retention, the Ag-K specimen exhibits IEP at a $\mathrm{pH}$ of 6.2. The IEP of a mineral is the $\mathrm{pH}$ at which zeta potential is zero (Pansu and Gautheyrou 2006). The results imply that retention of silver as $\mathrm{AgO}$ and exchangeable silver imposes a net positive charge on the clay surface at $\mathrm{pH}<6.2$. The Ag-K suspension (solids: water ratio, 1:2.5) is characterized by an alkaline $\mathrm{pH}$ of 9.0, apparently from hydrolysis of retained $\mathrm{AgO}$ as per reaction 1. The IEP value (6.2) of the $\mathrm{Ag}-\mathrm{K}$ suspension implies that the material is characterized by a net negative charge at $\mathrm{pH}$ 9.0. Theoretically, the negative charge of the $\mathrm{Ag}-\mathrm{K}$ specimen at $\mathrm{pH} 9$ should cause it to repel iodide ions. However, the next section shows that iodide ions are retained by formation of the AgI phase (reaction 2), implying that iodide retention by $\mathrm{Ag}-\mathrm{K}$ is independent of in situ $\mathrm{pH}$ conditions.

\section{lodide Retention Studies}

Tests with Ag-Kaolinite

Fig. 7 plots the kinetics of iodide sorption using an Ag-K specimen from a $1,000 \mathrm{mg} / \mathrm{L}$ iodide solution. The $\mathrm{pH}$ of $1,000 \mathrm{mg} / \mathrm{L}$ of the iodide the solution is 5.3. Addition of $0.5 \mathrm{~g}$ of a $\mathrm{Ag}-\mathrm{K}$ specimen to $(100 \mathrm{ml})$ iodide solution increased its $\mathrm{pH}$ to between 9 and 10 . The plot shows that iodide removal is a very rapid process and is complete in approximately 5 min. At equilibrium,the $\mathrm{Ag}-\mathrm{K}$ specimen exhibits $74 \%$ iodide removal, whereas the 90B-10AgK and $80 \mathrm{~B}-20 \mathrm{AgK}$ specimens remove 7 and $13 \%$ of the initially present iodide ions.

Fig. 8 plots iodide sorption by Ag-K specimens as a function of initial iodide concentration. Iodide sorption increases rapidly up to initial concentrations of $750 \mathrm{mg} / \mathrm{L}$ and thereafter tends to attain equilibrium. At equilibrium, the Ag-K specimen sorbs approximately $59 \mathrm{meq} / 100 \mathrm{~g}$ of iodide ions. The $\mathrm{Ag}-\mathrm{K}$ specimen is characterized by $125 \mathrm{meq} / 100 \mathrm{~g}$ of nonexchangeable silver (in the form of $\mathrm{AgO}$ ) and $14 \mathrm{meq} / 100 \mathrm{~g}$ of exchangeable silver (Table 3).

Measurements of solution $\mathrm{pH}$ during the iodide sorption experiments revealed that the acidic sodium iodide solutions $(\mathrm{pH} 5$ to 


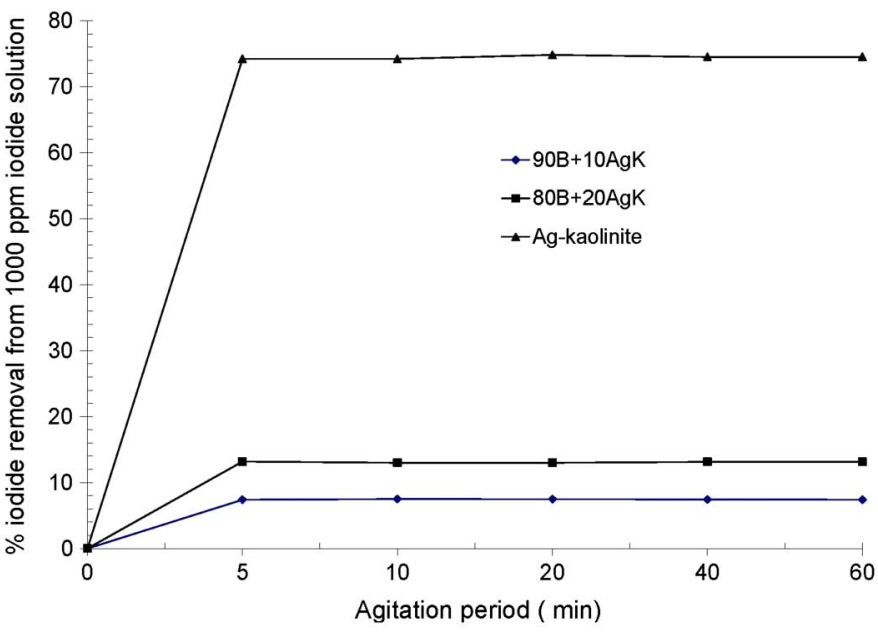

Fig. 7. Kinetics of iodide removal from $1,000 \mathrm{mg} / \mathrm{L}$ iodide solution

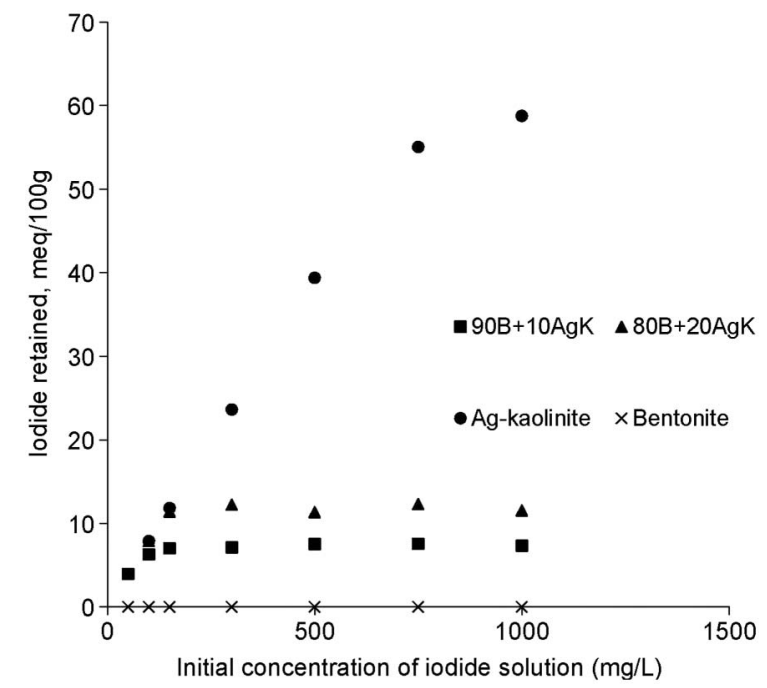

Fig. 8. Iodide sorption by Ag-kaolinite as a function of initial iodide concentration

5.67) were rendered alkaline ( $\mathrm{pH} 9.11$ to 9.48 ) through equilibration with the Ag-K specimen (Table 4). The alkaline $\mathrm{pH}$ of the iodide solutions on equilibration of the Ag-K specimen is attributed to the occurrence of hydrolysis and exchange reactions. The hydrolysis reaction is visualized to occur first; the $\mathrm{AgO}$ retained on the kaolinite surface hydrolyze (as per reaction 1) on contact with the aqueous solution to form insoluble $\mathrm{AgOH}$ and $\mathrm{OH}^{-}$ions. To examine the hypotheses for the occurrence of hydrolysis at contact

Table 4. $\mathrm{pH}$ of Iodide Solution on Equilibration with Ag-Kaolinite Specimen

\begin{tabular}{lcc}
\hline $\begin{array}{l}\text { Iodide solution } \\
\text { concentration }(\mathrm{mg} / \mathrm{L})\end{array}$ & $\begin{array}{c}\mathrm{pH} \text { of solution } \\
\text { before equilibration }\end{array}$ & $\begin{array}{c}\mathrm{pH} \text { of solution } \\
\text { after equilibration }\end{array}$ \\
\hline 88 & 4.98 & 9.11 \\
226 & 5.05 & 9.36 \\
469 & 5.14 & 9.48 \\
759 & 5.35 & 9.45 \\
998 & 5.67 & 9.31 \\
\hline
\end{tabular}

of Ag-kaolinite with the aqueous medium, the Ag-K specimen was equilibrated with distilled water (solids:solution ratio $=1: 100$ ); the $\mathrm{pH}$ of the suspension (measured as a function of time) increased almost immediately $(1 \mathrm{~min})$ to 8.9 on contact with distilled water (Fig. 9). The subsequent gradual decrease in the $\mathrm{pH}$ of the Ag-Kdistilled water suspension from 8.9 to 8.29 (after $150 \mathrm{~min}$ of agitation) is attributed to dehydroxylation of silanol ( $\mathrm{Si}-\mathrm{OH})$ groups at particle edges according to the reaction

$$
\mathrm{Si}-\mathrm{OH}+\mathrm{OH}^{-} \longrightarrow \mathrm{Si}^{-} \mathrm{O}^{-}+\mathrm{H}_{2} \mathrm{O}
$$

Sequent to $\mathrm{AgOH}$ formation, iodide ions from the salt solution are postulated to replace the hydroxyl groups of $\mathrm{AgOH}$ (as per reaction 2) that result in the formation of the AgI phase and release of additional $\mathrm{OH}^{-}$ions to the solution. Evidence for such a chemical reaction is provided by the XRD pattern of the Ag-K specimen equilibrated with a $1,000 \mathrm{mg} / \mathrm{L}$ sodium iodide solution (Fig. 10) that shows a peak at $0.375 \mathrm{~nm}$ characteristic of AgI phase.

Fig. 9 traced the increase in the $\mathrm{pH}$ of distilled water on contact with the Ag-K specimen. The $\mathrm{pH}$ of distilled water increased to 8.9 almost immediately. Comparing the relative rates of iodide retention (Fig. 7) and hydrolysis of Ag-K specimen (Fig. 9), the slower $\mathrm{OH}-\mathrm{I}$ exchange appears to be the rate determining step in the iodide retention process.

Fig. 6 includes the zeta potential of $\mathrm{Ag}-\mathrm{K}$ specimen contacted with a $0.01 \mathrm{M}$ sodium iodide solution whose $\mathrm{pH}$ was varied from 3-11 during the course of the experiment. The plot in Fig. 6 shows that on exposure to the iodide solution, the $\mathrm{Ag}-\mathrm{K}$ specimen acquires a larger negative zeta potential than the unexposed $\mathrm{Ag}-\mathrm{K}$ specimen at most $\mathrm{pH}$ values (except $\mathrm{pH} 7$ ). Iodide sorption alters the surface charge on the Ag-K specimen such that it exhibits a negative zeta potential even in the acid $\mathrm{pH}$ range.

Fig. 11 plots the iodide leached from the iodide sorbed Ag-K specimen as a function of solution $\mathrm{pH}$. Forty eight $\mathrm{mg}$ of iodide were adsorbed per $g$ of $\mathrm{Ag}-\mathrm{K}$ specimen on equilibrating the clay with a $500 \mathrm{mg} / \mathrm{L}$ iodide solution. On agitation of the iodide sorbed Ag-K specimen, with strongly acidic $(\mathrm{pH}=2.5)$ to strongly alkaline $(\mathrm{pH}=12.5)$ solutions, a negligible $(0.06 \mathrm{mg})$ amount of iodide was released by the specimen, indicating that iodide retention by the $\mathrm{Ag}-\mathrm{K}$ specimen is practically irreversible even under extreme $\mathrm{pH}$ conditions.

\section{Tests with Bentonite-Ag-K Specimens}

Fig. 7 includes the retention from a $1,000 \mathrm{mg} / \mathrm{L}$ iodide solution using $80 \mathrm{~B}-20 \mathrm{AgK}$ and $90 \mathrm{~B}-10 \mathrm{AgK}$ specimens. The $\mathrm{pH}$ of the iodide solution was not controlled and increased from an initial value of 5.7 to 9.3 at the end of equilibration. Dilution of bentonite with 10 and $20 \% \mathrm{Ag}-\mathrm{K}$ did not affect the rate of iodide retention and the process was completed in $5 \mathrm{~min}$. Fig. 8 shows the results of the iodide sorption experiments conducted with $\mathrm{B}, 80 \mathrm{~B}-20 \mathrm{AgK}$, and 90B-10AgK specimens. Bentonite does not adsorb iodide ions (Fig. 8) as they are repulsed by the negatively charged clay surface (Mitchell 1993; van Olphen 1963). Fig. 6 includes the variations in the zeta potential of bentonite as a function of suspension $\mathrm{pH}$ and the expansive clay exhibits zeta potential values ranging from -13 millivolts at $\mathrm{pH} 3.6$ to -14.8 millivolts at $\mathrm{pH} 9.6$; the net negative charge impairs iodide retention by these clay particles. Bentonite is observed to exhibit larger negative zeta potential than kaolinite at common $\mathrm{pH}$ (Fig. 6).

The Ag-K specimen shows strong affinity for iodide retention for reasons elaborated previously. The 90B-10AgK specimen shows iodide sorption capacity of approximately $6 \mathrm{meq} / 100 \mathrm{~g}$, whereas the $80 \mathrm{~B}-20 \mathrm{AgK}$ specimen shows iodide retention capacity of approximately $12 \mathrm{meq} / 100 \mathrm{~g}$ (Fig. 8). The B-Ag-K specimens attain sorption equilibrium at an iodide concentration of $300 \mathrm{mg} / \mathrm{L}$, 


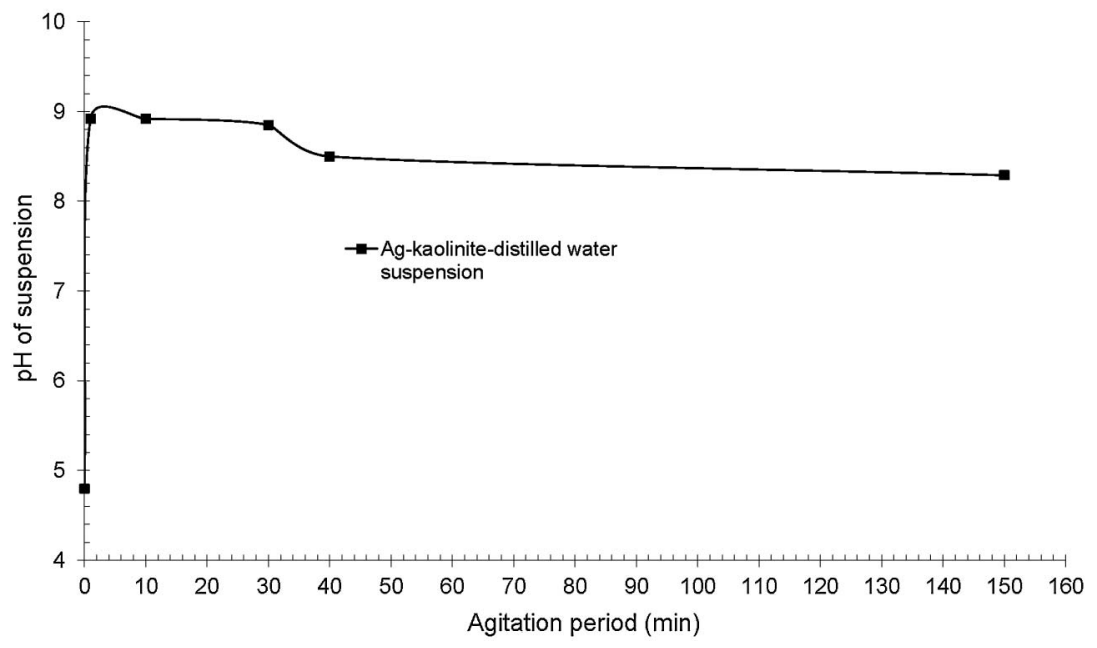

Fig. 9. $\mathrm{pH}$ variation of $\mathrm{Ag}$-kaolinite suspension over time

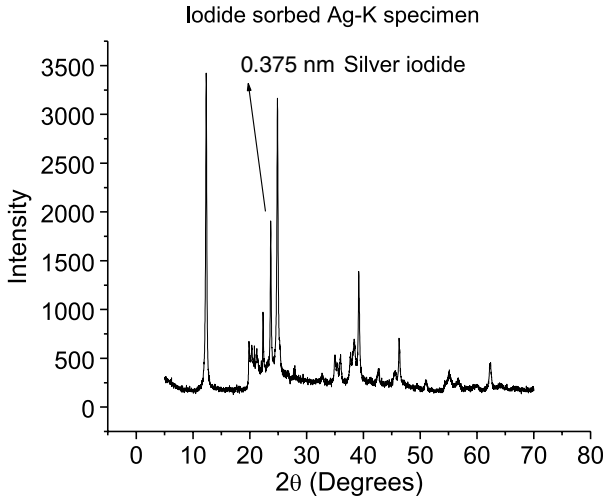

Fig. 10. XRD pattern of Ag-kaolinite equilibrated with $1,000 \mathrm{mg} / \mathrm{L}$ iodide solution

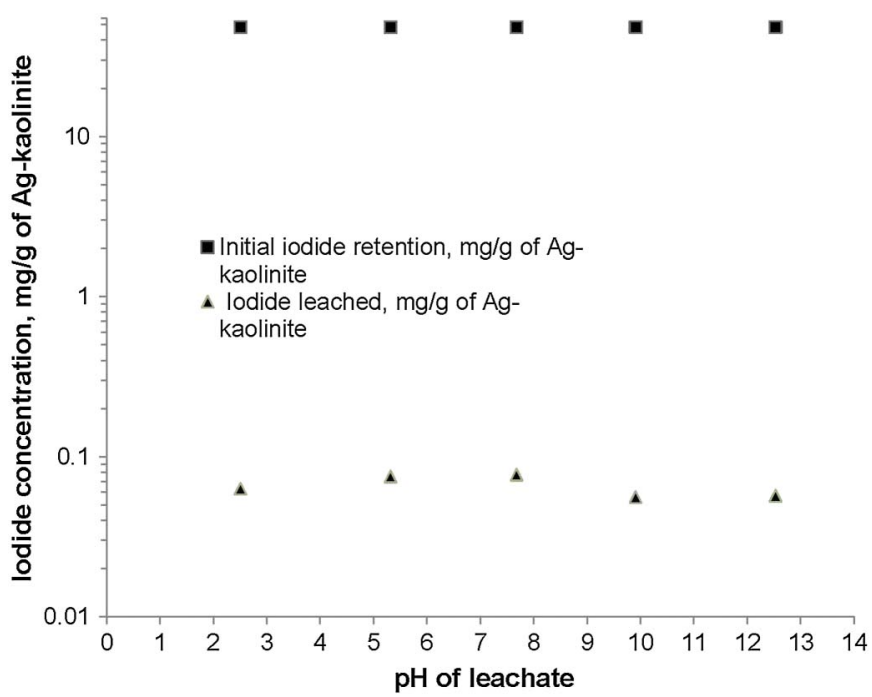

Fig. 11. Iodide leached from $\mathrm{Ag}$-kaolinite as a function of solution $\mathrm{pH}$

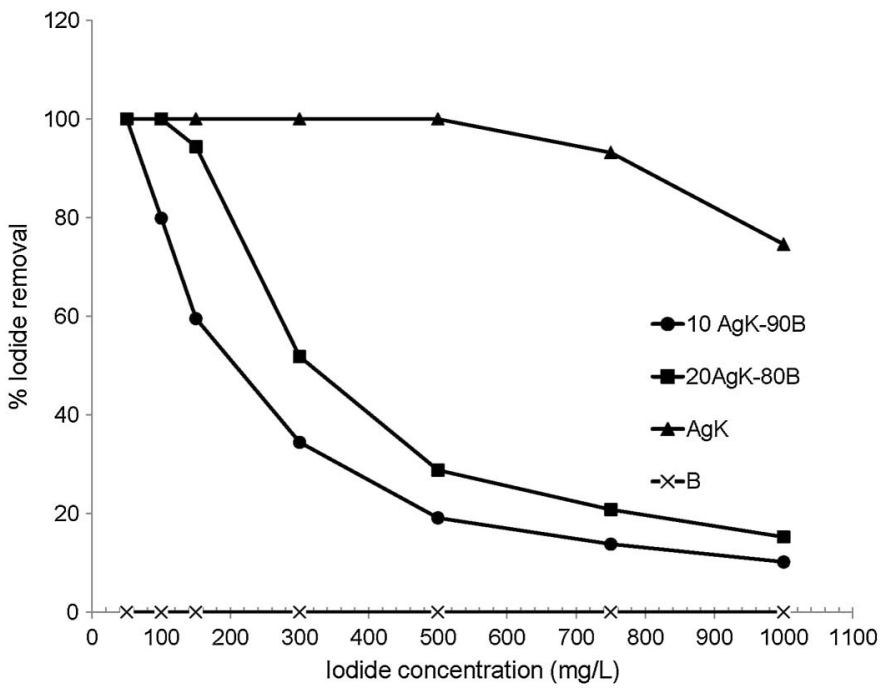

Fig. 12. Percent iodide removal plots

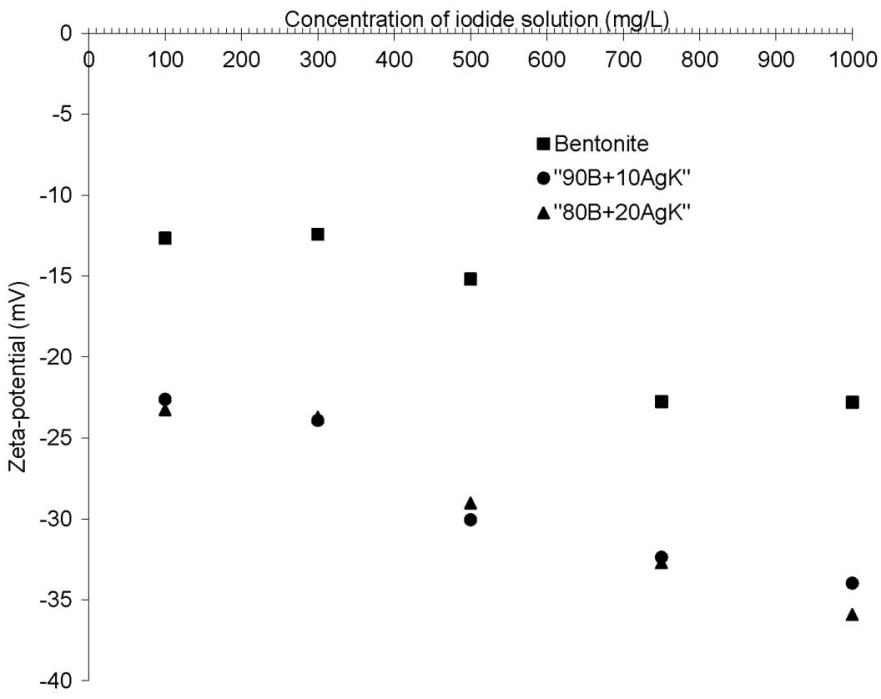

Fig. 13. Zeta potential variation as a function of iodide concentration 


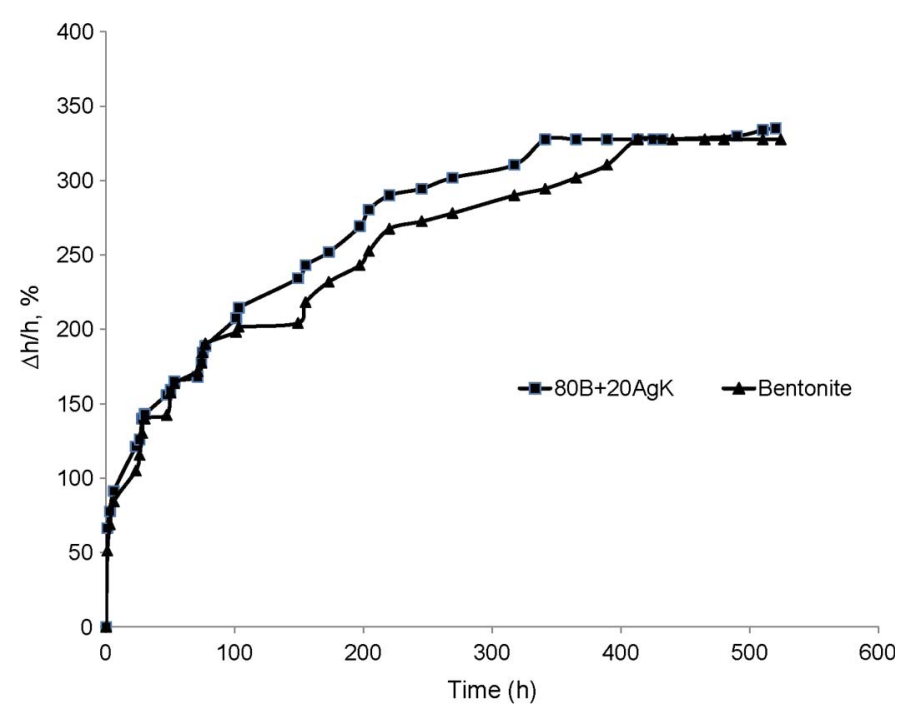

Fig. 14. Time-percent swell plots for compacted bentonite and $80 \mathrm{~B}-20 \mathrm{AgK}$ specimens

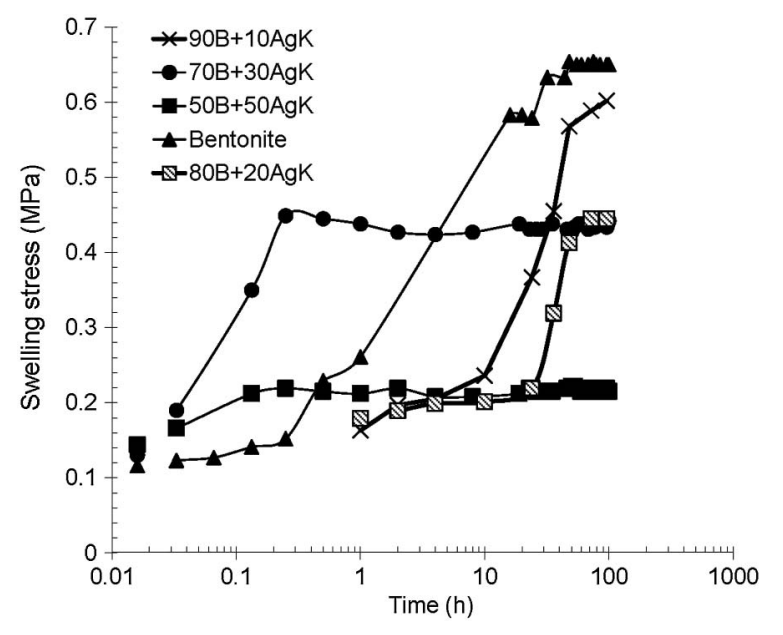

Fig. 15. Time--swelling stress plots which is lower than the value observed for Ag-K $(750 \mathrm{mg} / \mathrm{L}$, Fig. 8). Fig. 12 plots percent iodide removal as a function of initial iodide concentration. Ag-kaolinite scavenges all iodide ions from solutions containing iodide concentrations of up to $500 \mathrm{mg} / \mathrm{L}$. The 90B-10AgK and 80B-20AgK specimens exhibit $100 \%$ removal up to iodide concentrations of $100 \mathrm{mg} / \mathrm{L}$.

Fig. 13 plots the variations in zeta potential values of $B$, 80B-20AgK, and 90B-10AgK specimens equilibrated with varying iodide concentrations. The zeta potential of bentonite increases from -12.65 millivolts to -22.8 millivolts with an increase in iodide concentration from 100 to $750 \mathrm{mg} / \mathrm{L}$. On addition of electrolytes, the zeta potential of clay particles is expected to decrease because of a shift of counterions toward the Stern layer when the diffuse ion layer is compressed (van Olphen 1963; Mitchell 1993). The increase in zeta potential in Fig. 13 indicates that the anionic component of the electrolyte (iodide) and not of the cationic component (sodium) has a dominating effect on the zeta potential values and enhances particle repulsion with an increase in the solution's iodide concentration. The 80B-20AgK and 90B-10AgK specimens develop more negative zeta potentials than bentonite at a given iodide concentration, apparently the result of retention of iodide on the particle surface by chemical reaction mechanisms.

\section{Swell Potential and Swell Pressure Measurements}

Fig. 14 plots percent swell as function of time for the compacted bentonite and $80 \mathrm{~B}-20 \mathrm{AgK}$ specimens. Both specimens were compacted to a dry density of $1.5 \mathrm{Mg} / \mathrm{m}^{3}$ at $25 \%$ water content. The compacted specimens develop similar swell potentials of $330 \%$, indicating that dilution of bentonite with $20 \%$ Ag-K does not reduce the swell potential of the expansive clay.

The similar swell potentials developed by bentonite and $80 \%$ bentonite $+20 \%$ Ag-kaolinite suggest that the oedometer swell potential measurements were not sensitive enough to capture the effects of dilution on the swelling ability. Complete development of swelling strains by $B$ and $80 \mathrm{~B}-20 \mathrm{AgK}$ specimens needed a relatively long period of 480 to $530 \mathrm{~h}$. Swell pressure developments by similarly compacted $B$ and $80 \mathrm{~B}-20 \mathrm{AgK}$ specimens required a relatively shorter period ranging from 15 min to $44 \mathrm{~h}$ (Fig. 15). To evaluate the influence of Ag-K dilution on the swelling characteristics of bentonite, the study resorted to swell pressure

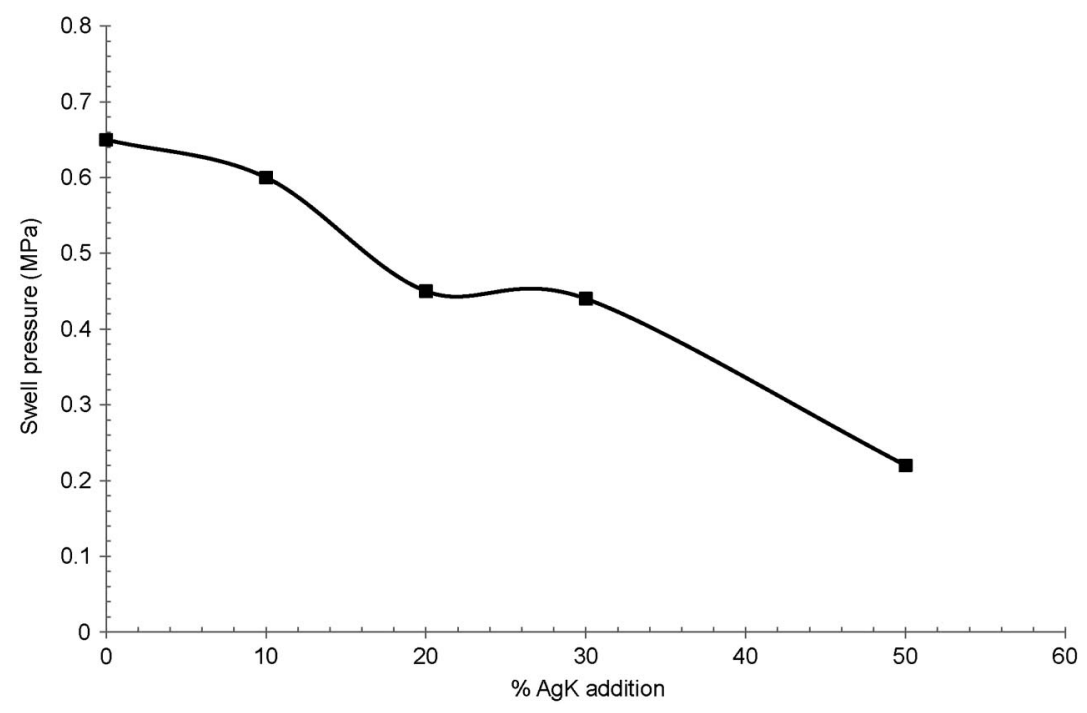

Fig. 16. Influence of Ag-K dilution on swell pressure of bentonite 
measurements. Fig. 16 plots the swell pressure as a function of $\mathrm{Ag}-\mathrm{K}$ content of the compacted mix. All specimens were compacted to a dry density of $1.5 \mathrm{Mg} / \mathrm{m}^{3}$ at $25 \%$ water content. The swell pressure values responded differently and showed reduction on dilution by $\mathrm{Ag}-\mathrm{K}$. Ten percent dilution caused an $8 \%$ reduction in swell pressure with respect to the undiluted $(100 \%$ bentonite) specimen. Twenty and 30\% dilutions caused 31 to $32 \%$ reduction in swell pressure values, whereas $50 \%$ dilution caused a $66 \%$ reduction (Fig. 16). During reprocessing of used nuclear fuel, volatile iodine species are released as $\mathrm{HI}$ and $I_{2}$ from the dissolution of the fuel rods in nitric acid (Schmett 2005). Schmett (2005) simulated $I_{2}$ generation during dissolution of spent nuclear fuel rods and observed I-129 concentrations ranging from 0.1 to $2 \mathrm{ppm}$. Superposing the field I-129 concentration levels on $I$ removal efficiency (Fig. 13) suggests that use of a 90B-10AgK mix would suffice to provide $100 \%$ removal efficiency. Use of 90B-10AgK also ensures that the swelling characteristics of bentonite are least affected by dilution. The proportional decrease in swell pressure on Ag-K dilution and the enhanced iodide retention results of B-Ag-K specimens bring out that mixing Ag-K with bentonite does not chemically modify the expansive clay; further mixing is only physical in nature with the Ag-K presence contributing to iodide retention.

\section{Conclusions}

The results of mass balance calculations, amounts of silver retained by kaolinite, and XRD analysis indicate that heating $20 \%$ of silver nitrate-kaolinite mix causes $85 \%$ of the silver nitrate contained in the mix to participate in the thermal decomposition reaction with the reactions product being retained on the clay surface. Further, $90 \%$ of the retained silver exists as fixed silver $(\mathrm{AgO})$ and the remaining $10 \%$ is retained in the exchangeable $\left(\mathrm{Ag}^{+}\right)$form. Kaolinite does not exhibit an isoelectric point (IEP) over the $\mathrm{pH}$ range of 2.9 to 9.9. However, on silver retention, the Ag kaolinite exhibits IEP at $\mathrm{pH}$ of 6.2. The iodide retention by Ag-kaolinite is attributed to occurrence of hydrolysis and exchange reactions. On contacting the Ag-kaolinite specimens, the $\mathrm{AgO}$ species hydrolyze to form $\mathrm{AgOH}$; iodide ions are retained by replacing the hydroxyl group of $\mathrm{AgOH}$, leading to formation of the $\mathrm{AgI}$ phase. The $\mathrm{I}-\mathrm{OH}$ exchange is the rate determining step in the iodide retention process. The Ag-kaolinite specimens acquire relatively large negative zeta potential values at all experimental $\mathrm{pH}$ values $(-16$ millivolts at $\mathrm{pH}=4.1$ to -20 millivolts at $\mathrm{pH}=9$ ) on iodide retention. The strong negative charge of bentonite excluded iodide retention. Mixing bentonite with 10 and 20\% Ag-kaolinite (on a dry mass basis) imparted iodide adsorption capacities of 6 and $12 \mathrm{meq} / 100 \mathrm{~g}$, respectively. The 90B-10AgK and 80B-20AgK specimens developed more negative zeta potential on iodide retention, indicative of dominance of anionic than cationic effect in the presence of electrolytes. Marginal release of iodide retained by Ag-kaolinite occurred under extreme acidic $(\mathrm{pH}=2.5)$ and alkaline $(\mathrm{pH}=12.5)$ conditions. The swell pressure and the iodide retention results of $\mathrm{B}-\mathrm{Ag}-\mathrm{K}$ specimens showed that mixing $\mathrm{Ag}-\mathrm{K}$ with bentonite is a physical process and the presence of Ag-K only contributes to iodide retention. Superposing the field I-129 concentration levels on $I$ removal efficiency indicate that use of the 90B-10AgK mix would suffice to provide $100 \%$ iodide removal efficiency and ensure that the swelling characteristics of bentonite are least affected by dilution.

\section{References}

Balsley, S. D., Brady, P. V., Krumhansl, J. L., and Anderson, H. L. (1998). "Anion scavengers for low-level radioactive waste repository backfills." J. Soil Contam., 7(2), 125-141.

Breen, C. (1999). "The characterisation and use of polycation-exchanged bentonites." Appl. Clay Sci., 15(1-2), 187-219.

Bureau of Indian Standards (BIS). (1980a). "Indian standard methods of tests for soils-Part 3." IS: 2720, Determination of specific gravity of fine grained soils, New Delhi, India.

Bureau of Indian Standards (BIS). (1980 b). "Indian standard methods of tests for soils-Part 7." IS: 2720, Determination of water content-dry density relation using light compaction, New Delhi, India.

Bureau of Indian Standards (BIS). (1985a). "Indian standard methods of tests for soils-Part 4.” IS: 2720, Determination of grain size analysis, New Delhi, India.

Bureau of Indian Standards (BIS). (1985b). "Indian standard methods of tests for soils-Part 5." IS: 2720, Determination of liquid and plastic limits, New Delhi, India.

Cotton, F. A., Wilkinson, G., and Gaus, P. L. (1995). Basic inorganic chemistry, 3rd ed., Wiley, New York.

Daniels, E. A., and Rao, S. M. (1983). "Silver sorption by metakaolinite from molten silver nitrate." Z. Phys. Chem., 137(2), 247-254.

Dultz, S., and Bors, J. (2000). "Organophilic bentonites as adsorbents for radionuclides. II. Chemical and mineralogical properties of HDPy-Montmorillonite." Appl. Clay Sci., 16(1-2), 15-29.

Hesse, P. R. (1971). A textbook of soil chemical analysis, John Murray, London.

Hossner, L. R. (2002). "Dissolution for total elemental analysis." Methods of soil analysis part-3 chemical methods, J. M. Bigham, ed., Soil Science Society of America, Madison, WI, 49-64.

Inyang, H. I., Bae, S., Mbamalu, G., and Park, S. W. (2007). "Aqueous polymer effects on volumetric swelling of Na-Montmorillonite." J. Mater. Civ. Eng., 84-90.

Kallai, L. H. (1978). "Reactions of salts with kaolinite at elevated temperatures. I." Clay Minerals, 13(2), 221-235.

Kaufhold, S., Pohlmann-lortz, M., Dohrmann, R., and Nuesch, R. (2007). "About possible upgrade of bentonite with respect to iodide retention capacity." Appl. Clay Sci., 35(2), 39-46.

Mitchell, J. K. (1993). Fundamentals of soil behaviour, Wiley, New York.

Pansu, M., and Gautheyrou, J. (2006). Handbook of soil analysis: Mineralogical, organic and inorganic methods, Springer, New York.

Pennell, K. D. (2002). "Specific surface area." Methods of soil analysis part 4: Physical methods, J. H. Dane, and G. C. Topp, eds., Soil Science Society of America Book Series No. 5, Soil Science Society America, Madison, WI, 295-315.

Perry, H. R., Green, W. D., and Maloney, O. J. (1999). Perry's chemical engineers' handbook, 7th Ed., McGraw Hill, New York.

Pusch, R. (2008). Geological storage of radioactive waste, Springer, Berlin.

Rao, S. M. (2006). "Identification and classification of expansive soils." Expansive soils: Recent advances in characterization and treatment, A. A. Rawas, and M. F. A. Goosen, eds., Taylor and Francis, London, $15-224$.

Riebe, B., Dultz, S., and Bunnenberg, C. (2005). "Temperature effects on iodine adsorption on organo-clay minerals. I. Influence of pretreatment and adsorption temperature." Appl. Clay Sci., 28(1-4), 9-16.

Sazarashi, M., Ikeda, Y., Seki, R., and Yoshikawa, H. (1994). "Adsorption of $\mathrm{I}^{-}$ions on minerals for ${ }^{129} \mathrm{I}$ waste management." J. Nucl. Sci. Technol., 31(6), 620-622.

Schmett, G. T. (2005). "Immobilization of fission iodine by reaction with fullerene containing carbon compounds or insoluble natural organic matter." M.Sc. dissertation, Graduate College, Univ. of Nevada, Las Vegas.

Toyohara, M., et al. (2000). "Iodine sorption onto mixed solid alumina cement and calcium compounds." J. Nucl. Sci. Technol., 37(11), 970-978.

van Olphen, H. (1963). An introduction to clay colloid chemistry, Wiley, New York.

Yukselen, Y., and Kaya, A. (2003). "Zeta potential of kaolinite in the presence of alkali, alkaline earth and hydrolyzable metal ions." Water Soil Air Pollution, 145(1), 155-168. 